\title{
Teknologi Akuaponik sebagai Solusi Kemandirian Pangan Keluarga di Kelompok Kampung Wolulas Kecamatan Turen Kabupaten Malang
}

\author{
Aquaponic Technology as a Solution for Family Food Resilience \\ in the Wolulas Village Group, Turen District, Malang Regency
}

\begin{tabular}{l|r}
\hline Riza Rahman Hakim ${ }^{1}$, Hariyadi ${ }^{凶}$ & \multicolumn{1}{|c}{ Riwayat naskah: } \\
12 Jurusan Perikanan, Fakultas Pertanian-Peternakan, & Diterima: 21 Desember 2020 \\
Universitas Muhammadiyah Malang & Disetujui: 14 Januari 2021 \\
hariyadi@umm.ac.id & Diterbitkan: 16 Januari 2021 \\
\hline
\end{tabular}

\begin{abstract}
Aquaponics is a technology that combines fish and vegetable cultivation at one system. Aquaponics can be used as an alternative to drive food resilience at the family level. For it can also provide benefits for improving family nutrition by fulfilling animal and vegetable protein, it is necessary to disseminate this technology to the public. The implementation of this service community program aims to disseminate aquaponic technology to the community, especially in Kampung Wolulas Group, Turen District of Malang Regency. The method used in the program was to provide solutions and basic information related to aquaponics, which was implemented through training and applications as well as partner assistance. There were three models of appropriate aquaponic technology applied, namely the bucket pond, the round tarpaulin pond, and the square tarpaulin pond. The cultivation results showed the survival rate of catfish by $65 \%$ and the feed conversion ratio of 1,1. Based on the results of the aquaponics, it is more expected to be a solution for family food resilience, especially in partner groups.
\end{abstract}

Keywords: aquaponics; catfish; food resilience; vegetable cultivation.

\begin{abstract}
Abstrak: Akuaponik merupakan teknologi yang menggabungkan budidaya ikan dan tanaman sayuran dalam satu periode budidaya. Teknologi akuaponik bisa dijadikan alternatif untuk menggerakkan kemandirian pangan di tingkat keluarga. Karena sangat berguna untuk memberikan manfaat bagi peningkatan gizi keluarga melalui pemenuhan gizi protein hewani dan nabati, perlu adanya diseminasi teknologi akuaponik ini kepada masyarakat. Pelaksanaan program pengabdian ini bertujuan untuk mendiseminasikan teknologi akuaponik pada masyarakat khususnya di Kelompok Kampung Wolulas Kecamatan Turen, Kabupaten Malang. Metode yang digunakan dalam pelaksanaan Program Pengabdian Kelompok ini adalah memberikan solusi dan informasi dasar terkait teknologi akuaponik di kelompok mitra, yang dilaksanakan melalui kegiatan pelatihan dan aplikasi teknologi, serta pendampingan mitra. Terdapat 3 model teknologi tepat guna akuaponik yang diaplikasikan, yaitu model akuaponik dengan kolam bak ember, kolam terpal bundar, dan kolam terpal kotak. Hasil budidaya menunjukkan keberhasilan hidup ikan lele sebesar 65\% dan rasio konversi pakan (FCR) sebesar 1,1. Dengan hasil penerapan teknologi akuaponik ini diharapkan dapat menjadi solusi kemandirian pangan keluarga khususnya di kelompok mitra.
\end{abstract}

Kata kunci: akuaponik; budidaya sayuran; ikan lele, kemandirian pangan. 


\section{Pendahuluan}

Potensi perikanan, khususnya subsektor perikanan budidaya, memiliki peran strategis menjadi salah satu penopang utama pemenuhan kebutuhan pangan nasional, seiring pertumbuhan penduduk yang terus meningkat signifikan dari tahun ke tahun. Hasil survey nasional juga menunjukkan rata-rata pendapatan pembudidaya ikan Tahun 2017 berada pada angka Rp. 3,3 juta per bulan atau naik dibanding tahun 2016 yang mencapai Rp. 3,021 juta per bulan. Angka ini berada jauh di atas standar garis kemiskinan yang ditetapkan Badan Pusat Statistik (BPS) (Direktorat Jenderal Perikanan Budidaya, 2017).

Tren budidaya ikan ini juga mulai berkembang di masyarakat perkotaan (urban) dengan menerapkan budidaya yang intensif. Namun, meskipun ada perkembangan budidaya ikan di perkotaan, masih belum banyak yang menerapkan teknologi akuaponik. Secara umum sistem budidaya akuaponik merupakan sistem budidaya ikan yang terpadu dengan memanfaatkan secara terus menerus air dari pemeliharaan ikan ke tanaman dan sebaliknya dari tanaman ke kolam ikan. Akuaponik adalah teknik budidaya tanaman yang terintegrasi dengan budidaya hewan air, seperti ikan, udang, serta moluska (Ghaly et al., 2005; Rakocy et al., 2016; Endut et al., 2010). Inti dasar dari sistem teknologi ini adalah penyediaan air yang optimum untuk masing-masing komoditas dengan memanfaatkan sistem resirkulasi. Sistem teknologi akuaponik ini muncul sebagai jawaban atas adanya permasalahan semakin sulitnya mendapatkan sumber air yang sesuai untuk budidaya ikan, khususnya di lahan sempit (Bernstien, 2011; Pantanella et al., 2006; Savidova et al., 2007).

Keunggulan akuaponik dibandingkan dengan budidaya konvensional berbasis tanah, di antaranya adalah tidak memerlukan pupuk serta pestisida, sangat efisien dalam penggunaan air, dapat dilakukan pada lahan non pertanian, produktivitas tinggi, menghasilkan dua produk sekaligus yakni tanaman dan ikan, produk yang dihasilkan terkategori organik dan bebas cemaran kimia dan biologi, efisien tenaga kerja, serta dapat dilakukan oleh setiap orang pada berbagai lapisan umur (Somerville et al., 2014; Roosta et al., 2011).

Upaya pengembangan budidaya akuaponik ini sebenarnya juga bisa dilakukan dengan memberikan sosialisasi dan pelatihan pada masyarakat di perkotaan maupun di wilayah pedesaan, meski utamanya untuk di perkotaan karena memiliki isu keterbatasan lahan. Pertumbuhan penduduk yang semakin tinggi di kawasan perkotaan, selain menimbulkan dampak negatif berupa luaran dalam bentuk sampah (Nurcahyo et al., 2020), juga menuntut suplai masukan berupa bahan makanan, baik yang diperoleh dari luar ataupun dari dalam lingkungan rumah tangga sendiri. Namun untuk dapat memproduksi bahan makanan secara mandiri, penduduk perkotaan sering terbentur dengan permasalahan lahan. Kondisi rumah perkotaan yang cenderung memiliki luas tanah yang sempit, perlu didorong untuk melakukan konsep budidaya urban farming. Pemasyarakatan model pertanian atau perkebunan yang dapat dipraktikkan oleh penduduk kota makin penting untuk dilakukan guna memberikan informasi dan pengetahuan dasar kepada masyarakat, khususnya dalam budidaya ikan dan sayuran yang ramah lingkungan dan dapat dilakukan di lahan yang terbatas.

Salah satu kelompok masyarakat yang saat ini sedang aktif dalam kegiatan peduli lingkungan adalah Kelompok Kampung Wolulas. Penamaan ini berdasarkan dari lokasi kelompok ini yang berada di RW 18 (Wolulas berarti Delapan Belas dalam bahasa Jawa), J1. Pegadaian Gang 1 Kelurahan Turen Kecamatan Turen Kabupaten Malang. Selanjutnya kelompok 
ini yang menjadi mitra dalam program pengabdian yang akan dilaksanakan. Dalam pelaksanaan kegiatan peduli lingkungan, Kampung Wolulas sudah melakukan beberapa upaya penghijauan di wilayah tersebut, di antaranya program penanaman sayuran daun maupun buah di setiap rumah, tanaman toga, serta bank sampah. Kemudian, saat pengabdian ini dilakukan, pengelola Kelompok Kampung Wolulas sedang melakukan penghijauan penanaman bermacam-macam pohon buah di sekitar kantor balai RW 18. Selain aktif dalam penghijauan, salah satu program yang ingin dicapai kelompok ini adalah menjadikan program ketahanan dan kemandirian pangan di wilayahnya. Dengan kondisi luas lahan yang terbatas, maka program akuaponik ini merupakan solusi yang kongkrit untuk bisa menyelesaikan permasalahan tersebut.

Secara umum, program pengabdian ini dirancang sebagai upaya untuk memberikan keterampilan pada masyarakat tentang teknologi akuaponik. Di samping itu juga mendorong masyarakat khususnya Kampung Wolulas Turen agar memanfaatkan lahan yang terbatas untuk budidaya ikan dan sayuran yang higienis, ramah lingkungan, dan aman dikonsumsi. Bila kesadaran masyarakat dalam menerapkan teknologi akuaponik tercapai, maka kemandirian pangan di tingkat keluarga akan dengan sendirinya terpenuhi. Dampak positifnya ke depan adalah semakin terpenuhinya gizi keluarga, khususnya protein hewani maupun nabati.

\section{Metode}

Metode yang digunakan dalam kegiatan pengabdian ini meliputi metode ceramah, demonstrasi dan praktek lapangan yang disertai tanya jawab serta diakhiri dengan evaluasi dan pendampingan selama 3 bulan pada Juli hingga September 2020. Rangkaian metode diharapkan dapat memberikan solusi dan informasi dasar terkait teknologi akuaponik, yaitu teknologi yang mengkombinasikan budidaya ikan dan sayuran di kelompok Kampung Wolulas Turen Kabupaten Malang yang dilaksanakan melalui kegiatan pelatihan dan aplikasi teknologi, serta pendampingan mitra. Kegiatan pengabdian ini dilakukan oleh tim yang terdiri dari 2 orang dosen Fakultas Pertanian-Peternakan Universitas Muhammadiyah Malang dan 2 orang mahasiswa. Tim dosen sebagai pelaksana pengabdian bertugas memberikan materi pelatihan dan pendampingan penerapan teknologi akuaponik. Sedangkan mahasiswa bertugas sebagai tim teknis dalam pelaksanaannya.

Adapun tahapan dalam aplikasi teknologi akuaponik ini adalah sebagai berikut:

1. Pembuatan kolam terpal bundar

2. Pemasangan kolam

3. Proses penyemaian tanaman

4. Penebaran ikan

5. Perawatan akuaponik (ikan dan sayuran)

6. Pemanenan ikan dan sayuran

Teknologi akuaponik yang diterapkan di kelompok mitra terdapat 3 model, yaitu model akuaponik dengan kolam bak ember, model akuaponik dengan kolam terpal bundar, dan model akuaponik dengan kolam terpal kotak. Penerapan aplikasi 3 model teknologi akuaponik dimaksudkan agar kelompok mitra bisa memilih teknologi yang akan diaplikasikan di rumah masing-masing. 
Pada rangkaian kegiatan, khususnya dalam pelatihan teknologi akuaponik juga menggunakan instrumen untuk mengukur keberhasilan kegiatan pelatihan. Kriteria keberhasilan kegiatan ini dapat diukur dengan tercapainya lima kriteria yang menjadi target capaian kegiatan, yaitu: tingkat partisipasi, tingkat pemahaman, tingkat ketrampilan, dan keberlanjutan (Siswoyo et al., 2021). Skala instrument yang digunakan adalah skala likert. Skala likert merupakan skala yang digunakan untuk mengukur sikap, pendapat, dan persepsi seseorang atau kelompok orang tentang kejadian atau gejala sosial (Janti, 2014). Adapun jumlah peserta pada saat pelatihan berlangsung adalah sebanyak 20 orang.

\section{Hasil dan Pembahasan}

Pengabdian ini telah dijalankan dengan beberapa tahapan kegiatan. Adapun tahapan kegiatan tersebut adalah sebagai berikut:

\section{Identifikasi skala prioritas penyelesaian permasalahan di kelompok mitra}

Pada tahap awal adalah melakukan survey untuk mengetahui permasalahan yang dihadapi oleh kelompok mitra. Selanjutnya setelah dilakukan identifikasi secara mendalam maka permasalahan mitra adalah bagaimana melakukan budidaya ikan dan tanaman dalam luas lahan yang terbatas. Berdasarkan hasil identifikasi skala prioritas program adalah kelompok mitra sekarang membutuhkan teknologi tepat guna yang bisa mendukung ketahanan pangan bagi keluarga, khususnya bidang pertanian dan perikanan yang memanfaatkan luas lahan terbatas.

\section{Mengenalkan teknologi akuaponik}

Berdasarkan identifikasi skala prioritas penyelesaian masalah yang ada, maka langkah awal yang kami lakukan adalah mengenalkan teknologi akuaponik pada kelompok mitra. Akuaponik adalah teknik budidaya tanaman yang terintegrasi dengan budidaya hewan air, seperti ikan, udang serta moluska. Beberapa keunggulan dari akuaponik ini antara lain: kualitas air bisa terjaga, air tidak menimbulkan bau menyengat, dan bisa panen 2 produk yaitu ikan dan sayuran. Pengenalan ini dimulai dengan pelatihan teknologi akuaponik dan dilanjutkan dengan praktek. Adapun teknologi akuaponik yang diterapkan di kelompok mitra terdapat 3 model, yaitu model akuaponik dengan kolam bak ember, model akuaponik dengan kolam terpal bundar, dan model akuaponik dengan kolam terpal kotak. Dari hasil pemaparan teknologi akuaponik tersebut, ternyata responnya sangat positif dengan harapan agar teknologi ini bisa diterapkan di kelompok mitra.

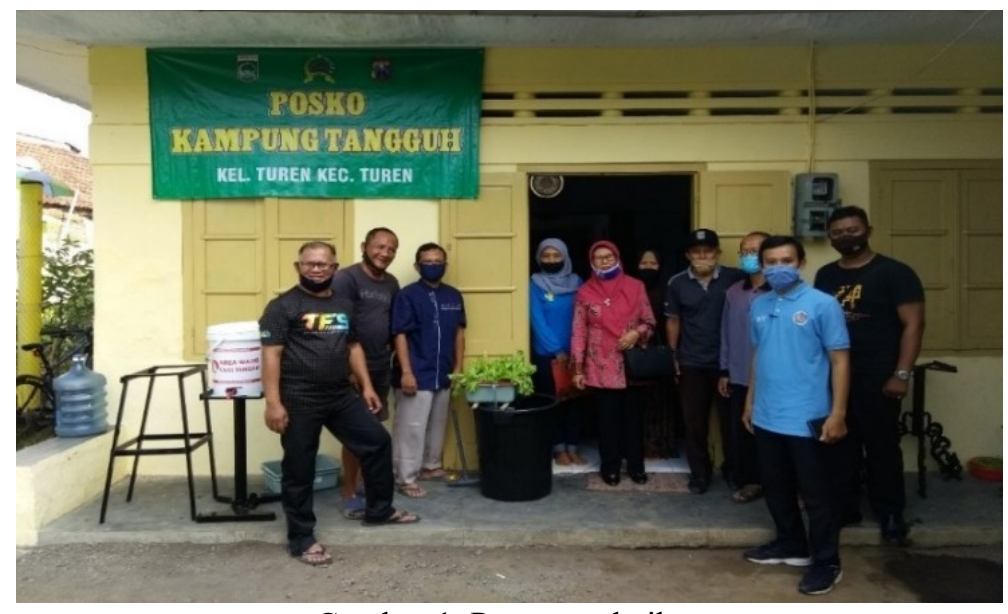

Gambar 1. Peserta pelatihan 
Pelatihan teknologi akuaponik dilaksanakan melalui ceramah, diskusi dan praktek. Materi pelatihan tentang konsep dasar akuaponik, persiapan air media, manajemen kualitas air, manajemen pemberian pakan, teknik semai tanaman, dan perawatan akuaponik. Peserta pelatihan (Gambar 1) dibatasi maksimal 20 orang mengingat masih dalam suasana pandemi Covid 19.

\section{Aplikasi akuaponik dalam budidaya ikan lele}

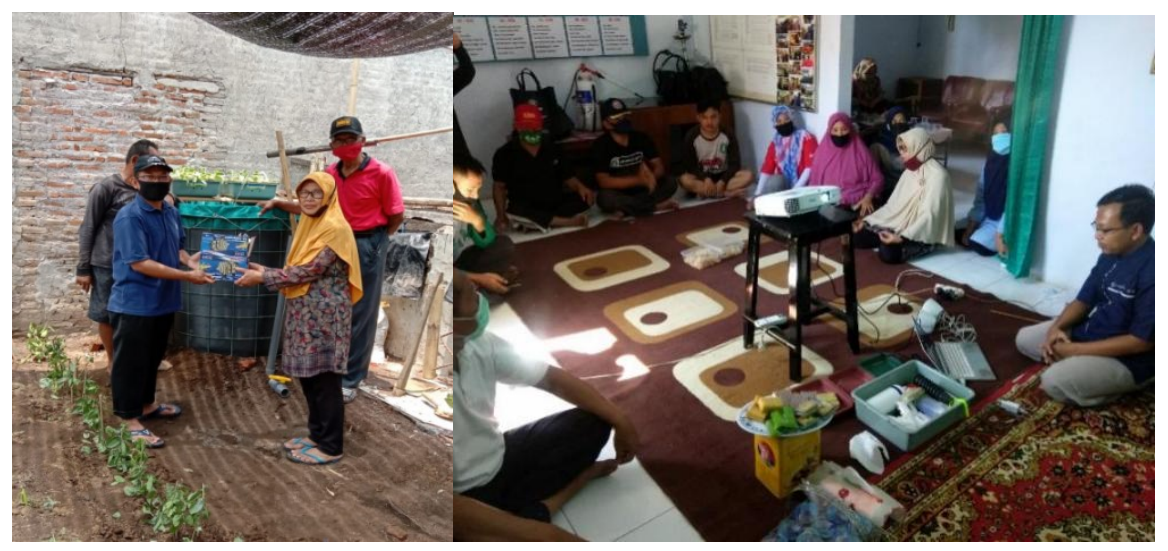

Gambar 2. Pelatihan simulasi dan praktik langsung teknologi akuaponik

Tahapan dalam aplikasi teknologi akuaponik dalam bentuk pelatihan dan praktik langsung (Gambar 2) dengan kolam terpal bundar adalah sebagai berikut:

a) Pembuatan kolam terpal bundar

Bahan yang digunakan dalam pembuatan kolam terpal adalah: terpal yang sudah berbentuk bundar (tabung), rangka besi (wiremesh), karet pelapis, dan perpipaan.

b) Pemasangan kolam

Kolam terpal bundar berdiameter $1 \mathrm{~m}$ dan tinggi $1 \mathrm{~m}$ dipasang di atas tanah yang sudah dibuat central drain untuk memudahkan pembuangan air. Setelah kolam terpasang dilanjutkan dengan pemasangan instalasi aerasi yang terdiri dari mesin aerasi, selang aerasi, dan batu aerasi.

c) Perlakuan media air

Setelah pemasangan kolam dan instalasi aerasi selesai, dilanjutkan dengan persiapan media dengan memberikan perlakuan pada media air tersebut. Perlakuan media air ini dengan memberikan kapur dolomit (3 sendok makan), garam grasak $(3 \mathrm{~kg})$, molase/tetes tebu (200 $\mathrm{ml})$, dan probiotik (200 ml). Selanjutnya aerasi dinyalakan dan didiamkan selama 7 hari.

d) Proses penyemaian tanaman

Penyemaian tanaman dilakukan dengan menggunakan media rockwool. Adapun jenis tanaman yang digunakan adalah selada dan sawi. Proses penyemaian memerlukan waktu 7 hari, kemudian dipindah ke dalam netpot untuk selanjutnya diletakkan di instalasi hidroponik yang berada di atas kolam. 
e) Penebaran ikan

Setelah 7 hari perlakuan air media, kemudian dilanjutkan dengan penebaran benih ikan lele. Padat tebar ikan lele sebanyak 500 ekor dengan ukuran $5 \mathrm{~cm}$. Lele dipuasakan 1 hari setelah penebaran.

f) Perawatan akuaponik

Perawatan akuaponik dilakukan dengan menajemen kualitas air dan manajemen pemberian pakan ikan. Manajemen kualitas air dilakukan seminggu sekali dengan mengganti air 30\% dan selanjutnya diberikan kapur 3 sendok makan, molase $20 \mathrm{ml}$, dan probiotik $50 \mathrm{ml}$. Sedangkan untuk pemberian pakan sebanyak 5\% per hari dari berat biomass ikan yang ada di kolam. Pemberian pakan dilakukan 2 kali sehari, yaitu pada pagi dan sore hari. Setiap kali pemberian pakan dicampur dengan probiotik dengan dosis $10 \mathrm{ml}$ per kg pakan.

g) Pemanenan ikan dan sayuran

Pemanenan ikan lele dilakukan setelah 3 bulan pemeliharaan, sedangkan untuk panen sayuran bisa dilakukan sebulan sekali panen.

Lebih lanjut berdasarkan program pengabdian tersebut terdapat 3 model teknologi tepat guna akuaponik yang diaplikasikan, yaitu model akuaponik dengan kolam bak ember, model akuaponik dengan kolam terpal bundar, dan model akuaponik dengan kolam terpal kotak. Hasil budidaya menunjukkan keberhasilan hidup ikan lele sebesar $65 \%$ dan rasio konversi pakan (FCR) sebesar 1,1. Dengan hasil penerapan teknologi akuaponik ini diharapkan dapat menjadi solusi kemandirian pangan keluarga khususnya di kelompok mitra.

\section{Tanggapan masyarakat setelah dilakukan kegiatan}

Program pengabdian pada masyarakat maka dilakukan evaluasi terhadap efektivitas kegiatan dengan diberikan kuisioner seputar tentang kegiatan pengabdian dan materi pelatihan. Hasil kuesioner dapat disajikan sebagai berikut:

\section{Pengetahuan masyarakat perihal usaha budidaya akuaponik}

Berdasarkan hasil kuisioner yang dapat dijelaskan pada Gambar 3, didapatkan bahwa peserta pengabdian setelah adanya program pengabdian yang mengetahui perancangan akuaponik sebanyak 9\%, sedangkan sisanya $91 \%$ belum pernah tahu cara perancangan akuaponik. Hal tersebut menunjukkan sebagian besar masyarakat lebih banyak tahu tentang budidaya ikan secara konvensional setelah dilakukan pengabdian di mana sebelumnya masyarakat belum mengenal sama sekali sistem budidaya ini.

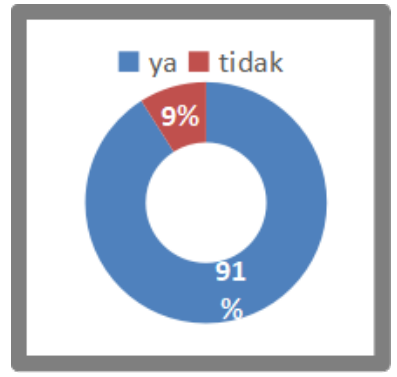

Gambar 3. Pengetahuan masyarakat perihal usaha akuaponik 


\section{Manfaat pelatihan dalam menambah pengetahuan dan keterampilan}

Berdasarkan Gambar 4. diketahui deskripsi manfaat pelatihan bagi peserta dalam meningkatkan pengetahuan, wawasan, dan keterampilannya. Masyarakat di kelompok tersebut sebelumnya belum memiliki keahlian di bidang budidaya sistem akuaponik. Kegiatan ini menunjukkan bahwa program pengabdian pada masyarakat ini $100 \%$ sangat berguna bagi semua peserta pelatihan, khususnya dalam menambah pengetahuan, dan keterampilan tentang pembuatan akuaponik.

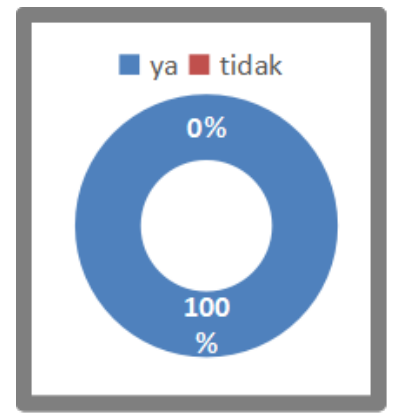

Gambar 4. Manfaat pelatihan dalam menambah pengetahuan dan keterampilan

\section{Tanggapan terhadap isi materi pelatihan}

Berdasarkan hasil kuesioner, memperlihatkan 98\% peserta sangat tertarik dengan pelatihan ini, dan hanya $2 \%$ yang kurang tertarik, karena isi materinya menarik, mudah dipahami, dan mudah untuk diaplikasikan. Hal tersebut berarti memperlihatkan langkah awal yang baik bagi para masyarakat untuk memulai usaha perancangan akuaponik. Nilai prosentase tanggapan peserta terhadap isi materi pelatihan dapat dilihat pada Gambar 5.

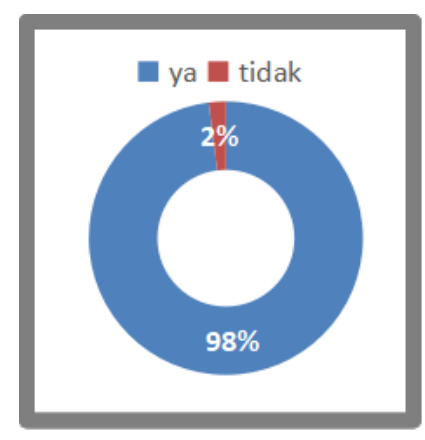

Gambar 5. Tanggapan peserta tentang isi materi pelatihan

\section{Ketertarikan peserta pada materi pelatihan}

Berdasarkan hasil kuesioner menunjukkan bahwa peserta sebagian besar, yaitu sebanyak 94\% tertarik pada praktek perancangan akuaponik daripada teori pelatihan ini. Lebih jelasnya terdapat pada Gambar 6. 


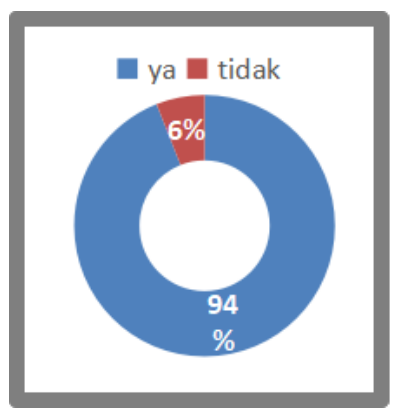

Gambar 6. Ketertarikan peserta pada pelatihan

\section{Keinginan peserta untuk usaha akuaponik}

Pelatihan perancangan akuaponik dengan kolam bundar ini ternyata memberikan dampak yang positif bagi para peserta, yaitu memberikan motivasi untuk mengembangkan usaha terutama dalam usaha perancangan akuaponik. Hal ini ditunjukkan sebanyak $86 \%$ peserta mempunyai keinginan untuk membuat usaha sendiri. Hasil ini menunjukkan indikasi yang baik untuk mengaplikasikan praktek hasil pelatihan. Berikut Gambar 7, grafik yang menunjukkan keinginan peserta untuk membuat usaha budidaya sistem akuaponik.

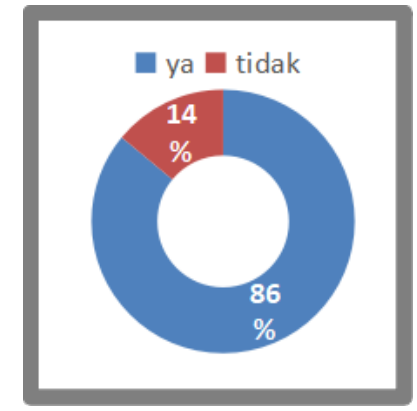

Gambar 7. Keinginan peserta untuk membuat usaha budidaya sistem akuaponik

Secara umum hasil ini sangat direspon positif oleh masyarakat, mulai dari manfaat pelatihan, isi dan cara penyajian, serta keinginan peserta untuk mengaplikasikannya. Hal ini dikarenakan masyarakat bisa memulai usaha tanpa modal yang besar, mudah dilakukan dan sangat menguntungkan. Kegiatan perancangan akuaponik memiliki peluang pasar sangat besar, sehingga kegiatan ini sangat prospektif bila dikembangkan di kemudian hari. Agar pelaksanaan program ini dapat berkelanjutan maka dilakukan adanya kegiatan tindak lanjut.

\section{Kesimpulan}

Kesimpulan dari pelaksanaan program pengabdian ini adalah sebagai berikut: Pertama, rangkaian program pengabdian kepada masyarakat ini meliputi beberapa kegiatan dengan rincian kegiatan, yaitu: pelatihan teknologi tepat guna akuaponik, pembuatan akuaponik, persiapan media air, cara semai tanaman, serta perawatan akuaponik. Kedua, teknologi tepat guna akuaponik yang diterapkan dalam program ini dapat diterima dengan baik untuk kemandirian pangan keluarga. Terbukti dengan antusiasme dari anggota kelompok mitra yang mulai banyak menerapkan 
teknologi akuaponik di rumahnya, bahkan ada juga yang akan menjadikan usaha ekonomis produktif skala rumah tangga.

Adapun saran dari kegiatan ini adalah agar kelompok mitra bisa lebih memperhatikan dalam perawatan akuaponiknya, khususnya manajemen kualitas air dan perawatan tanamannya. Secara ringkas, tahap selanjutnya dari program pengabdian ini adalah proses pendampingan secara periodik tiap 2 minggu sekali selama 3 bulan dengan observasi secara langsung ke lapangan, meliputi aktivitas memantau pertumbuhan ikan, pemantauan kualitas air, manajemen pemberian pakan ikan, dan perawatan tanaman dan sayuran.

\section{Referensi}

Bernstien, S. (2011). Aquaponic Gardening: a step-by-step guide to raising vegetables and fish together. New Society Publishers.

Direktorat Jenderal Perikanan Budidaya. (2017). Statistik Perikanan Budidaya Indonesia. Departemen Kelautan dan Perikanan. Direktorat Jenderal Perikanan Budidaya Kementerian Kelautan dan Perikanan Republik Indonesia.

Endut, A., Jusoh, A., Ali, N., Wan Nik, W. B., \& Hassan, A. (2010). A study on the optimal hydraulic loading rate and plant ratios in recirculation aquaponic system. Bioresource technology, 101(5), 1511-1517. https://doi.org/10.1016/j.biortech.2009.09.040

Ghaly, A. E., Kamal, M., \& Mahmoud, N. S. (2005). Phytoremediation of aquaculture wastewater for water recycling and production of fish feed. Environment international, 31(1), 1-13. https://doi.org/10.1016/j.envint.2004.05.011

Janti, S. (2014). Analisis Validitas Dan Reliabilitas Dengan Skala Likert Terhadap Pengembangan SI/TI dalam Penentuan Pengambilan Keputusan Penerapan Strategic Planning Pada Industri Garmen. Prosiding Seminar Nasional Aplikasi Sains \& Teknologi (SNAST) 2014 Yogyakarta.

Nurcahyo, R., Adiputra, I., \& Pangestu, F. (2020). Inovasi Alarm dan Kedisiplinan Masyarakat dalam Manajemen Pembuangan Sampah Rumah Tangga di Perkotaan. Amalee: Indonesian Journal of Community Research and Engagement, 1(2), 149-157. https://doi.org/10.37680/amalee.v1i2.384

Pantanella, E., Cardarelli , M., Colla, G., Rea , E. and Marcucci, A. (2012). Aquaponics vs. Hydroponics: Production and Quality of Lettuce Crop. Acta Hortic. 927, 887-893 https://doi.org/10.17660/ActaHortic.2012.927.109

Rakocy, J., Masser, M. P., \& Losordo, T. (2016). Recirculating aquaculture tank production systems: aquaponics-integrating fish and plant culture. Retrieved from https://extension.okstate.edu/fact-sheets/recirculating-aquaculture-tank-production-systemsaquaponics-integrating-fish-and-plant-culture.html

Roosta, H. R., \& Hamidpour, M. (2011). Effects of foliar application of some macro-and micronutrients on tomato plants in aquaponic and hydroponic systems. Scientia Horticulturae, 129(3), 396-402. https://doi.org/10.1016/j.scienta.2011.04.006

Savidov, N.A., Hutchings, E. and Rakocy, J.E. (2007). Fish and Plant Production in a Recirculating Aquaponic System: a New Approach to Sustainable Agriculture in Canada. Acta Hortic. 742, 209-221 https://doi.org/10.17660/ActaHortic.2007.742.28 
Teknologi Akuaponik sebagai Solusi Kemandirian Pangan Keluarga di Kelompok Kampung Wolulas

Kecamatan Turen Kabupaten Malang / Riza Rahman Hakim \& Hariyadi

Siswoyo, B., Hasan, U., \& Manullang, H. (2021). Budidaya Ikan Lele dengan Teknologi Bioflok di Kelurahan Nelayan Indah. RESWARA: Jurnal Pengabdian Kepada Masyarakat, 2(1), 1-6. doi: https://doi.org/10.46576/rjpkm.v2i1.635

Somerville, C., Cohen, M., Pantanella, E., Stankus, A., \& Lovatelli, A. (2014). Small-scale aquaponic food production: integrated fish and plant farming. FAO Fisheries and Aquaculture Technical Paper, (589), I. 